\title{
FORMING THE CONSUMER SOCIETY IN THE USSR: CHALLENGES FOR AUTHORITIES (1964-1982)
}

\author{
Fedor L. Sinitsyn \\ Institute of World History of the Russian Academy of Sciences, Moscow, Russian Federation
}

\begin{abstract}
Introduction. In the 1960s, the formation of a consumer society began in the USSR. At the same time, the differences in living standard and quality of life between the segments of the population became more and more noticeable. These phenomena were in conflict with the Soviet ideology - the basis of the political system of the USSR. However, the problem of the consumer society formation in the USSR and the associated challenges to the Soviet system have not yet been sufficiently studied in historiography. Methods and materials. The methodological background of the research is based on the principles of scientific objectivity and historicism, as well as the general scientific and special methods typical for historical research. The research base includes both published and unpublished documents found by the author in the Russian State Archive of Contemporary History, the Russian State Archive of Socio-Political History and the Central State Archive of the City of Moscow. Analysis. The Soviet power tried to respond to the challenges of consumer society within the framework of the new political and ideological concept of Developed Socialism. One of the tasks of the country's development at this stage was declared to be the achievement of a high standard of living in the country, as well as the widespread introduction of a system of material incentives. This policy has had a certain effect. However, the previous challenges for the Soviet system remained, and new problems arose. The wage growth outstripped the growth of labor productivity, and the commodity deficit became one of the main reasons for the decline in the effectiveness of the material incentive system. To solve the problems listed above, the authorities introduced innovations in policy: reducing the rate of income growth and the population's desire to consume, increasing the role of moral incentives, fighting surplus money, and pursuing people for non-labor income. These innovations were in conflict with the policy aimed at increasing the welfare of the population. Results. Thus, the response of Soviet ideology to the challenges of the consumer society was to implement mutually exclusive measures. First, the authorities, while officially promoting a policy of increasing living standards, in practice sought to limit the growth of consumption. Second, material incentives to work and the rejection of equalization were introduced simultaneously with the censure of enrichment. In addition, the authorities failed to eradicate the negative manifestations of the consumer society for the Soviet ideology. In general, the inability of Soviet ideology to provide an adequate response to the challenges of consumer society was one of the manifestations of the ideological impasse in which the country was during the period under review. Problems related to the standard of living of the population became one of the time mines that undermined the Soviet system and led to its collapse.
\end{abstract} Brezhnev.

Key words: consumer society, standard of living, material incentives, moral incentives, deficit, USSR, Leonid

Citation. Sinitsyn F.L. Forming The Consumer Society in the USSR: Challenges for Authorities (1964-1982). Vestnik Volgogradskogo gosudarstvennogo universiteta. Seriya 4. Istoriya. Regionovedenie. Mezhdunarodnye otnosheniya [Science Journal of Volgograd State University. History. Area Studies. International Relations], 2021, vol. 26, no. 3, pp. 84-94. (in Russian). DOI: https://doi.org/10.15688/jvolsu4.2021.3.8

\section{ФОРМИРОВАНИЕ «ОБЩЕСТВА ПОТРЕБЛЕНИЯ» В СССР: ИДЕОЛОГИЧЕСКИЙ ВЫЗОВ ДЛЯ ВЛАСТИ (1964-1982 гГ.)}

\author{
Федор Леонидович Синицын
}

Институт всеобщей истории РАН, г. Москва, Российская Федерация 
Аннотация. В 1960-х гг. в СССР началось формирование «общества потребления», возрастали различия в уровне и качестве жизни разных слоев населения. Эти явления входили в конфликт с советской идеологией основой политической системы СССР. Власти страны пытались дать ответ на вызовы «общества потребления» в рамках новой политико-идеологической концепции «развитого социализма». Одной из задач этого этапа развития страны было объявлено достижение в стране высокого уровня жизни, а также была широко внедрена система материального стимулирования. Эта политика дала определенный эффект. Однако вызовы, с которыми до этого столкнулась советская система, сохранились, а также возникли новые проблемы. Рост оплаты труда стал опережать рост его производительности, а товарный дефицит стал одной из главных причин снижения эффективности системы материального стимулирования. Для решения перечисленных выше проблем власти ввели новшества в политику: снижение стремления населения к потреблению и темпов роста доходов, повышение роли морального стимулирования труда, борьба с «излишками» денег у населения, преследование за «нетрудовые доходы». Эти новшества входили в противоречие с политикой, направленной на рост благосостояния населения.

Ключевые слова: «общество потребления», уровень жизни, материальное стимулирование, моральное стимулирование, дефицит, СССР, Л.И. Брежнев.

Цитирование. Синицын Ф. Л. Формирование «общества потребления» в СССР: идеологический вызов для власти (1964-1982 гг.) // Вестник Волгоградского государственного университета. Серия 4, История. Регионоведение. Международные отношения. - 2021. - Т. 26, № 3. - С. 84-94. - DOI: https://doi.org/10.15688/ jvolsu4.2021.3.8

Введение. Формирование «общества потребления» в СССР - тема, имеющая высокую актуальность ${ }^{1}$. В последние десятилетия «общество потребления» во всем мире достигло пика своего развития. Важными остаются проблемы роста уровня жизни, благосостояния, а также осознанного потребления.

Задачей исследования, представленного в данной статье, является выявление вызовов для советской идеологии, связанных с формированием «общества потребления» в СССР, и ответа властей Советского Союза на эти вызовы в период правления Л.И. Брежнева (1964-1982).

Методы и материалы. Проблема формирования «общества потребления» в СССР и связанных с ним вызовов для советской системы еще недостаточно изучена в отечественной и зарубежной историографии. В имеющихся трудах раскрыты отдельные аспекты этой темы [8; 29; 30; 54].

Источниковая база исследования включает в себя как опубликованные, так и неопубликованные документы, выявленные автором в Российском государственном архиве новейшей истории, Российском государственном архиве социально-политической истории и Центральном государственном архиве г. Москвы. В этот комплекс источников входят в основном документы ЦК и МГК КПСС, а также других партийных и советских органов. В качестве источников использованы также со- ветские публикации, изданные в рассматриваемый период, которые содержат информацию об уровне жизни и потреблении в СССР.

В качестве методологической основы представленного в статье исследования взяты принципы научной объективности и историзма. Из числа общенаучных использованы исторический и логический методы, которые позволили раскрыть генезис, развитие и сущность явлений, рассматриваемых в статье. На основе исторического и логического методов применены методы системного анализа. В тесной связи с общенаучными методами использованы другие специальные методы, характерные для исторического исследования, в том числе хронологический, историко-описательный и историко-генетический.

Анализ. Особенностью рассматриваемого периода было повышение внимания населения СССР к проблеме материального благосостояния $[17$, л. $173 ; 19$, л. 9; 50, л. 259; 12 , л. $11-12 ; 13$, л. 130,$145 ; 38$, л. $32 ; 21$, л. 45; 22, л. 122; 23, л. 19-21]. В СССР началось формирование «общества потребления» с тенденцией к постоянному росту запросов со стороны населения [5, с. 88; 12 , л. $12 ; 48$, л. 58; 39 , л. 35; 27, л. 63], стала популярной «педагогика счастья»- воспитание детей с основным упором на удовлетворение материальных запросов. К концу 1970-х гг. рост материальных затрат на детей в семье в 1,5 раза опережал рост доходов семьи [42, л. 4]. 


\section{ИСТОРИЧЕСКИЙ ОПЫТ ПОЛИТИЧЕСКИХ ТРАНСФОРМАЦИЙ}

В стране возрастали различия в уровне и качестве жизни разных слоев населения (хотя они были меньше, чем в капиталистических странах) [57, p. 79]. Во-первых, принцип неравного распределения «по труду» позволял установить достаточно высокий размер зарплаты, гонораров, премий для отдельных работников. Во-вторых, имущественное неравенство проявлялось в сфере частного строительства [56, p. 43-44], во владении автомобилями [5, с. 88], бытовой техникой, мебелью и пр. Несмотря на то что в СССР были установлены ограничения на личное имущество [38, л. 22], некоторые люди их обходили - в первую очередь это касалось так называемой «номенклатуры», работников торговли, «снабженцев» и др. Из-за этого складывалось впечатление, что одни группы населения «переобеспечены», а другие - не имеют возможности даже «удовлетворить прожиточный минимум» [38, л. 21]. Кроме того, разница в уровне жизни имела «региональный» аспект [13, л. 145; 16, л. 17].

С одной стороны, рост уровня жизни, несомненно, был достижением и рассматривался властями как благо, с другой - сопутствовавшие ему явления входили в конфликт с «коммунистическими идеалами» и даже, как считали некоторые партийные идеологи, с «интересами общества» [52, с. 21].

Во-первых, происходило умаление моральных («идеологических») основ трудовой деятельности советских граждан в пользу материальных [38, л. 32]. Во-вторых, «идеалам» явно противоречило «обрастание» людей частной собственностью [31, с. 124]. «Обуржуазивание» советских людей отмечали иностранцы [18, л. 86].

Некоторые граждане СССР, сохранившие приверженность «идеалам», отрицательно реагировали на новые явления, считая, что из-за них советское общество пришло к «начальной стадии разложения». Они призывали срочно привести образ жизни советских людей в соответствие с марксистско-ленинской идеологией (вплоть до полной ликвидации частной собственности, к которой они относили дачи, автомобили и пр.) $[19$, л. $10 ; 16$, л. $17 ; 38$, л. $21,24,28,30-31,37]$. Кроме того, вызов неравномерности благосостояния способствовал росту социальной напряженности в стране [5, с. 88].
Советская идеология в рассматриваемый период попыталась дать ответ на вызовы «общества потребления», принимая во внимание и стремление людей к достатку, и заинтересованность государства в повышении производительности труда, и установки идеологии.

Во-первых, важность «материального фактора» и рост потребления фактически были обозначены как положительные явления $[3$, с. 3,$17 ; 46$, с. 200,203$)$, не мешающие духовной жизни человека и не противопоставленные ей [39, л. 35]. В свою очередь, государство декларировало свою обязанность обеспечивать население товарами и услугами [37, с. 22].

Во-вторых, была еще раз подчеркнута допустимость обладания личной собственностью [38, л. 23].

В-третьих, было объявлено, что, хотя «общественный интерес» имеет в СССР первенство, он должен «правильно, разумно сочетаться» с «личным интересом» [52, с. 22; 44 , c. $21 ; 45$, c. $48 ; 46$, c. 199$]$.

В-четвертых, власти декларировали относительную «нормальность» неравномерности благосостояния в стране. Мало того, была обозначена допустимость временного сохранения «частнособственнической психологии» (как «пережитка», который в будущем должен исчезнуть). Спокойному восприятию этого «пережитка» способствовала констатация, что его проявления на практике - это отдельные, редкие случаи [47, л. 8; 38, л. 23; 39, л. 37].

Практическое воплощение ответа властей СССР на вызовы «общества потребления» состояло в том, что, во-первых, одной из задач этапа «развитого социализма» было объявлено достижение в стране высокого уровня жизни [3, с. $17 ; 4 ; 37$, с. 5].

Главным инструментом повышения уровня жизни в СССР был рост заработной платы. В период с 1960 г. до середины 1970-х гг. доходы населения выросли почти в 2 раза, а к началу 1980-х гг. повысились еще в среднем на $17 \%$ [51, с. 4]. Кроме того, в СССР осуществлялись сокращение или отмена ряда налогов, повышение размеров пенсий и других видов социального обеспечения [37, с. 10]. В дополнение государство предоставляло гражданам пользование общественными фондами 
потребления (ОФП), обеспечивая бесплатное жилье, образование, здравоохранение, низкую стоимость некоторых товаров и услуг.

Одновременно для людей были расширены возможности владения собственностью, в том числе путем строительства «кооперативного» жилья, дач и гаражей. Так, в 1964 г. в жилищно-строительных кооперативах состояли 260 тыс., к концу 1971 г. - 1729 тыс. пайщиков [53, с. 4].

Во-вторых, во второй половине 1960-х гг. в СССР была широко внедрена система материального стимулирования труда (в том числе в рамках расширения хозрасчета, осуществленного в ходе «косыгинской реформы»). Была поставлена задача не допускать при начислении зарплаты «уравнительного подхода» [35, с. $15 ; 44$, с. 19].

Хотя моральное стимулирование также применялось (вручение правительственных наград, присвоение почетных званий, занесение на доску почета и пр.), однако в ходе «косыгинской реформы», как считает Т. Томпсон [59, p. 56], оно было практически «забыто» в пользу максимизации материального стимулирования. Это утверждение нужно откорректировать - моральное стимулирование было не забыто, а ушло на второй план. Кроме того, иногда присутствовала путаница между двумя видами стимулирования - так, добавление хорошо работающим людям дополнительных дней к отпуску представляли как моральное поощрение [50, л. 251], хотя оно, скорее, является материальным.

Политика, реализованная властями в сфере повышения благосостояния населения, дала определенный эффект. В 1965-1970 гг. личное потребление граждан страны увеличилось на $142 \%$, значительно улучшилось их питание, расширилось потребление промышленных товаров [39, л. 35] и платных услуг [32, c. 209-210] (Л.И. Брежнев отмечал, что «достигнутый уровень жизни трудящихся нужно расценивать как большую победу» [48, л. 58]). Система материального стимулирования во второй половине 1960-х гг. также показала свою действенность [7, с. 57-58; 51, с. 42].

Однако вызовы, с которыми столкнулась советская система, сохранялись. Введение системы материального стимулирования входило в определенный конфликт с «коммунис- тическими идеалами». Моральный, «идеологический» аспект труда на ряде предприятий был практически отброшен [1, с. 17]. Это обстоятельство было отмечено некоторыми западными советологами, которые увидели в новациях советской политики признак «движения на пути к разложению социализма и реставрации капитализма» [44, с. 18]. Советские идеологи, в свою очередь, оправдывали внедрение материального стимулирования недостаточной «сознательностью» основной массы граждан СССР, стремились представить материальную заинтересованность как «меньшее зло», временно допустимое явление $[35$, с. 13,$18 ; 44$, с. 21$]$.

Кроме того, советские идеологи в действительности предлагали смириться с тем, что «при социализме еще имеются проявления фактического неравенства» [52, с. 21]. На практике власти избегали сокращения доходов «номенклатуры» и приближенных к ней лиц, оправдывая это тем, что «существующие... высокие оклады заработной платы далеко не так велики, чтобы могли образовываться миллионные состояния» [38, л. 22].

Возможность установить значительный размер зарплат, премий и пр., во-первых, привела к тому, что рост оплаты труда часто стал опережать рост его производительности [7, c. $58 ; 44$, c. 18$])$.

Во-вторых, возникли разного рода злоупотребления. В 1975 г. власти выявили, что некоторые руководители предприятий и организаций производили из фондов материального поощрения выплаты «за выполнение работ, не связанных с производственной деятельностью», а также специально добивались снижения плановых заданий [26, л. 190-191]. В 1981 г., выступая на XXVI съезде КПСС, Л.И. Брежнев вновь указал на факты «выдачи незаслуженных премий» [9, с. 77].

С другой стороны, несмотря на введение премиальной системы, в стране в некотором роде сохранялась «уравниловка». Усилиями властей существенно сократилась разница между минимальной и средней заработной платой, что рассматривалось как положительное явление. Однако в итоге получилось, что все люди получали зарплату в среднем всего в два раза выше минимально установленной в стране [12, л. 12]. 


\section{ИСТОРИЧЕСКИЙ ОПЫТ ПОЛИТИЧЕСКИХ ТРАНСФОРМАЦИЙ}

Несмотря на начальную эффективность системы материального стимулирования и достигнутый рост уровня жизни, проблемы в экономике СССР не дали этим тенденциям развиться. В стране еще с начала 1960-х гг. отмечался дефицит «товаров народного потребления» [12, л. 12]. В 1970-х гг. во многих регионах периодически наблюдался острый недостаток продовольствия. К началу 1980-х гг. дефицит превратился в «бедствие национального масштаба» [8, с. 253-254; 29, с. 36-37]. Эта проблема вызывала все большее беспокойство населения [12, л. $12 ; 23$, л. $19 ; 28$, л. 17].

Товарный дефицит стал одной из главных причин торможения роста благосостояния в СССР [58, p. 35]. Так, к 1970 г., несмотря на рост потребления большинства продуктов питания, оно оставалось даже ниже норм, официально установленных в стране [32, c. 113]. Фактически сохранялась «хлебно-картофельная диета», усугубленная значительным потреблением сахара. Власть была вынуждена пересмотреть «нормы рационального потребления» в сторону их существенного снижения, что означало ухудшение структуры питания граждан СССР. Но и сниженные нормы не были достигнуты (за исключением потребления сахара) [30, с. 75].

Торможение роста потребления привело к снижению эффективности системы материального стимулирования, что отмечал в декабре 1972 г. Л.И. Брежнев [54, с. 371]. Значительная часть денег, которые выплачивались людям в виде заработной платы, оставалась неизрасходованной. Если в 19711986 гг. производство товаров потребления в СССР выросло в 2,1 раза, то количество денег в обращении - в 3,1 раза [29, с. 37]. Кроме того, из-за низкой производительности труда на многих производствах, их работники получали от государства гарантированную, но фактически не заработанную плату [55, с. 33], которая, соответственно, не была обеспечена товарами и услугами.

Разница между реальной (обеспеченной товарами и услугами) и фактической заработной платой граждан СССР явственно отразилась в солидной сумме их денежных сбережений [6, с. 247-248]. К 1981 г. остаток вкладов достиг 156,5 млрд руб. [29, с. 37], остаток наличных денег на руках у населения в 1964
1982 гг. увеличился с 1,03 до 3,81 млрд руб. [2, с. 114-132].

Дефицит способствовал росту «теневой экономики», расширению «спекуляции» [20, c. 12-13]. Советские граждане пытались «выкручиваться», «доставать» необходимые товары и услуги, что способствовало дальнейшему отходу от «коммунистических идеалов».

В связи с этим в 1970-х гг. и начале 1980-х гг. о «частнособственнических проявлениях» власти стали говорить, как о распространенном явлении. Стремление людей к благосостоянию все чаще рассматривалось теперь как «стяжательство» [34, с. 66], «рвачество» [33, с. 335], «накопительство». Иногда даже вполне нормальное с точки зрения социалистического общества желание жить лучше воспринималось «в штыки». Сюда же относилась критика «педагогики счастья» [12, л. $12 ; 42$, л. $4 ; 39$, л. $37 ; 25$, л. 19].

Для решения перечисленных выше проблем власти ввели новшества в политику. Вопервых, трудности роста уровня жизни было решено нивелировать путем снижения стремления советских граждан к потреблению. Кроме того, был признан обоснованным «некоторый разрыв между потребностями населения и возможностями общества их удовлетворить» $[40$, с. $7 ; 3$, с. 17$]$.

Для того чтобы поставить потребление под контроль, граждан СССР призывали руководствоваться официально установленными «рациональными нормами потребления» [32, с. $76 ; 43$, с. 5]. Советская идеология делала упор на пропаганду осознанного потребления и порицание «культа потребления», в возникновении которого обвиняли Запад [14, л. 207; 39, л. 34-35, 37].

Во-вторых, был сделан упор на «сознательность» в труде. В «материальном аспекте» этот упор проявился во внушении людям, что распределение доходов в СССР происходит именно «по труду» [31, с. 124], и поэтому каждый, кто желает хорошо заработать, должен и хорошо трудиться. В «идейном аспекте» пропагандировалось первенство «общественного интереса» и «коллективной материальной заинтересованности» [37, с. 9; 46, c. 198]. Советская идеология и пропаганда апеллировали к энтузиазму людей [10, л. 8; 49, л. 15]. Однако действенность таких лозунгов 
не была высокой, так как, согласно данным социологических исследований, проведенных в СССР в рассматриваемый период, уровень энтузиазма в советском обществе существенно снизился.

Практическим воплощением использования упора на «сознательность» было усиление роли морального стимулирования труда. Кроме того, фактически пресекалось подкрепление морального стимулирования материальным [15, л. 7; 11, л. 14].

Во второй половине 1970-х гг. произошел новый пересмотр политики, имевший целью формирование более сбалансированного подхода к моральному и материальному стимулированию. Власти понимали, что материальное поощрение необходимо сохранять, однако были ужесточены требования к такому поощрению [59, p. 49, 59-60]. В целом считалось лучшим решением сочетание материального и морального стимулирования «соответственно конкретным условиям». Кроме того, усилилось стремление представлять материальное стимулирование в качестве «морального» $[1$, с. $17-19 ; 36$, с. 8$]$.

Результаты продвижения морального стимулирования были слабыми, и к началу 1980-х гг. значительная часть трудящихся высказывала свое неудовлетворение последним [51, с. 42].

В-третьих, власти пытались снизить темпы роста доходов граждан. В сентябре 1968 г. Совет министров СССР принял постановление о недопущении роста зарплаты, если он опережает рост производительности труда. С 1970 г. предприятиям были установлены предельные ассигнования на содержание аппарата управления [7, с. 58-59]. В 1977 г. Госплан СССР предлагал вовсе отказаться от повышения заработной платы и ликвидировать премии [54, с. 359]. За злоупотребления материальным стимулированием применялись санкции [26, л. 193].

Было также объявлено, что в СССР осуществляется «ликвидация некоторых излишеств в оплате труда отдельных категорий работников». Однако на практике устранялись не «излишества», а «необоснованный разрыв в уровне оплаты» путем повышения зарплаты низкооплачиваемых работников [51, с. 8], а не снижения зарплаты высокооплачиваемых.
В-четвертых, власти вели борьбу с «излишками» денег у населения, пытаясь вывести их в оборот. Одним из главных инструментов этого процесса было повышение цен на многие продовольственные и промышленные товары, которое ежегодно происходило с 1968 г. [5, с. 177], что помогло несколько уменьшить избыточную денежную массу [29, c. 37]. Кроме того, поддерживались высокие цены на мебель, электронную, бытовую технику и другие товары.

Решение о массовом производстве в СССР легковых автомобилей, продажная цена которых была достаточно высока, было вызвано в том числе необходимостью вывода в оборот большой массы наличных денег, накопленных гражданами страны [41, с. 215]. Аналогичную функцию (как минимум, косвенно) имело создание жилищно-, дачно- и гаражно-строительных кооперативов, платных («хозрасчетных») поликлиник и пр.

В-пятых, извлечение гражданами СССР «нетрудовых доходов», получение «“левых" заработков» [34, с. 66] рассматривались как «нарушение социалистических законов», а люди, совершившие такие нарушения, подлежали преследованию по закону. На борьбу со «спекуляцией» имелся социальный запрос от населения [39, л. 37; 25, л. 19; 27, л. 38], которое все больше страдало от дефицита самых необходимых товаров. Однако на практике такие правонарушения далеко не всегда выявлялись, а санкции в отношении лиц, их совершивших, иногда были слабыми [24, л. 114].

Результаты. Таким образом, ответ советской идеологии на вызовы «общества потребления» заключался в реализации фактически взаимоисключающих мер. Во-первых, власти, официально пропагандируя рост уровня жизни и принимая соответствующие меры (повышение размера заработной платы, пенсий и пр.), на практике стремились ограничить рост потребления. Это вело к провалу одной из целей «развитого социализма» и подрыву доверия людей к государству.

Во-вторых, материальное стимулирование труда и отказ от «уравниловки» внедрялись одновременно с порицанием «обогащения». Кроме того, упор на материальное стимулирование и официальное признание «неравенства» людей в этом аспекте явно противо- 


\section{ИСТОРИЧЕСКИЙ ОПЫТ ПОЛИТИЧЕСКИХ ТРАНСФОРМАЦИЙ}

речили «коммунистическим идеалам». Власти сознавали это и пытались сгладить упор на материальное стимулирование путем комбинирования его с моральным, однако в итоге оказалось, что эффективность морального стимулирования была невысокой. В итоге не только моральное, но и материальное стимулирование не смогло достичь нужных результатов, так как заработанные деньги часто оставались у людей «мертвым грузом» из-за товарного дефицита.

Кроме того, власти не смогли искоренить «негативные» для советской идеологии проявления «общества потребления». Борьба с «обогащением» и «частнособственническими проявлениями», несмотря на заявления о ее успехах, не приносила должного результата. В стране росла «спекуляция» и «теневая экономика». Ударом по «идеалам» был явно более высокий, чем у «простых» граждан, уровень жизни «номенклатуры».

В целом неспособность советской идеологии дать адекватный ответ на вызовы «общества потребления» стала одним из проявлений «идеологического тупика», в котором страна оказалась в рассматриваемый период. Проблемы, связанные с реальным достижением высокого уровня жизни населения, стали одной из «мин замедленного действия», которые подорвали советскую систему и привели ее к краху.

\section{ПРИМЕЧАНИЕ}

${ }^{1}$ «Общество потребления» - это состояние социума, которое характеризуется массовым потреблением материальных благ и формированием соответствующей системы ценностей и установок.

\section{СПИСОК ЛИТЕРАТУРЫ}

1. Александров, А. И. Материальное и моральное стимулирование труда - важные факторы повышения эффективности и качества / А. И. Александров. - Л. : Изд-во СХИ, 1978. - 20 с.

2. Баланс денежных доходов и расходов населения СССР, 1924-1990 гг. (Эволюция в цифрах, персоналиях и методическом обеспечении) : сб. материалов. - М. : МБИ, 2007. - 308 с.

3. Бромлей, Н. Я. Уровень жизни в СССР (1950-1965 гг.) / Н. Я. Бромлей // Вопросы истории. 1966. - № 7. - C. 3-17.
4. Бурлацкий, Ф. О строительстве развитого социалистического общества / Ф. Бурлацкий // Правда. $-1966 .-21$ дек. - С. 4.

5. Вестник Архива Президента: Специальное издание: Генеральный секретарь Л.И. Брежнев: 1964-1982. - М., 2006. - 240 c.

6. Восленский, М. Номенклатура / М. Восленский. - М. : Захаров, 2016. - 640 с.

7. Голанд, Ю. Косыгинская реформа: упущенный шанс или мираж? / Ю. Голанд, А. Некипелов // Российский экономический журнал. - 2010. № 6. - С. 44-66.

8. Гущин, А. А. Обострение проблемы товарного дефицита в СССР в 1960-х - начале 1980-х гг. в ракурсе истории повседневности / А. А. Гущин // Проблемы гуманитарного образования: филология, журналистика, история : сб. науч. ст. III Междунар. науч.-практ. конф. - Пенза : Изд-во ПГУ, 2016. - C. 252-258.

9. XXVI съезд Коммунистической партии Советского Союза : стеногр. отчет. - М. : Политиздат, 1981. - T. I. -382 c.

10. Документы по подготовке материалов XXIV съезда КПСС // Российский государственный архив новейшей истории (РГАНИ), - Ф. 80. - Оп. 1. Д. 100.- 101 л.

11. Замечания Л.И. Брежнева, 1971 г. // РГАНИ. Ф. 104. - Оп. 1. - Д. 41. - 63 л.

12. Записки отдела, парторганов // РГАНИ. Ф. 5. - Оп. 60. - Д. 39. - 67 л.

13. Записки отдела, парторганов // РГАНИ. Ф. 5. - Оп. 63. - Д. 88. - 208 л.

14. Записки отделов ЦК КПСС // РГАНИ. Ф. 5. - Оп. 64. - Д. 71. - 247 л.

15. Записки отделов ЦК КПСС // РГАНИ. Ф. 5. - Оп. 67. - Д. 110. - 246 л.

16. Записки отделов ЦК КПСС // РГАНИ. Ф. 5. - ОП. 73. - Д. 243. - 22 л.

17. Записки, письма // РГАНИ. -Ф. 5. - Оп. 33. Д. 224. -190 л.

18. Записки, письма // РГАНИ. -Ф. 5. - Оп. 59. Д. 24. - 148 л.

19. Записки, письма Всесоюзного общества «Знание» // РГАНИ. - Ф. 5. - Оп. 33. - Д. 241. - 24 л.

20. Здравомыслов, А. Г. Социально-политические аспекты механизма торможения / А. Г. Здравомыслов // Механизм торможения: истоки, действие, пути преодоления. - М. : Политиздат, 1988. C. 9-24.

21. Информации (Бауманский РК КПСС) // Центральный государственный архив г. Москвы (ЦГАМ). - Ф. П-63. - Оп. 1. - Д. 2247. - 120 л.

22. Информации (Бауманский РК КПСС) // ЦГАМ. - Ф. П-63. - Оп. 1. - Д. 2288. - 131 л.

23. Информации (Бауманский РК КПСС) // ЦГАМ. - Ф. П-63. - ОП. 1. - Д. 2417. - 101 л. 
24. Информации (Бауманский РК КПСС) // ЦГАМ. - Ф. П-63. - ОП. 1. - Д. 2463. - 143 л.

25. Информации (Бауманский РК КПСС) // ЦГАМ. - Ф. П-63. - ОП. 1. - Д. 2500. - 190 л. 26. Информации (МГК КПСС) // ЦГАМ. Ф. П-4. - Оп. 172. - Д. 50. - 193 л.

27. Информации (Пролетарский РК КПСС) // ЦГАМ. - Ф. П-80. - ОП. 1. - Д. 1788. - 124 л.

28. Информации (Сокольнический РК КПСС) // ЦГАМ. - Ф. П-85. - Оп. 1. - Д. 2262. - 168 л.

29. Кирсанов, Р. Г. Состояние потребительского рынка в СССР (конец 1970-х - начало 1990-х гг.) / Р. Г. Кирсанов // Вестник Бурятского государственного университета. - 2014. - № 7. - С. 36-41.

30. Клинова, М. А. Нормы рационального питания в СССР второй половины 1950-х - 1980-х гг.: причины и векторность трансформаций / М. А. Клинова // Ученые записки : электрон. науч. журн. Курского гос. ун-та. Исторические науки и археология. - 2017. № 4 (44). - С. 73-78. - Электрон. текстовые дан. Режим доступа: http://scientific-notes.ru/\#newnumber?id=49 (дата обращения: 18.08.2020). - Загл. с экрана.

31. Козлов, Г. Об этапах развития коммунистического способа производства / Г. Козлов // Вопросы экономики. - 1971. - № 7. - С. 115-128.

32. Комаров, В. Е. Доходы и потребление населения СССР / В. Е. Комаров, У. Г. Чернявский. - М. : Наука, 1973. - 238 с.

33. Коммунистическая партия Советского Союза в резолюциях и решениях съездов, конференций и пленумов ЦК. - М. : ИМЛ при ЦК КПСС, 1987. - T. 13. -509 c.

34. Косолапов, Р. Вклад XXIV, XXV и XXVI съездов КПСС в разработку теоретических и политических проблем развитого социализма и перехода к коммунизму / Р. Косолапов // Коммунист. - 1982. № 5. - С. 54-67.

35. Мальцев, Н. А. Материальное и моральное стимулирование труда в промышленности / Н. А. Мальцев. - М. : Мысль, 1965. - 95 с.

36. Материальное и моральное стимулирование работников и предприятий. - Киев : Знание, 1976. $-29 \mathrm{c}$.

37. Михайлов, М. Что решил сентябрьский пленум ЦК КПСС : Меры по дальнейшему повышению благосостояния советского народа / М. Михайлов, А. Мотылев. - М. : Политиздат, 1967. - 32 с.

38. Переписка редакции журнала «Коммунист» // Российский государственный архив социально-политической истории (РГАСПИ). - Ф. 599. Оп. 1. - Д. 274. - 116 л.

39. Переписка редакции журнала «Коммунист» // РГАСПИ. - Ф. 599. - Оп. 1. - Д. 692. - 108 л.

40. Планирование народного потребления в СССР (современные проблемы) / под ред.
В. Ф. Майера и П. Н. Крылова. - М. : Экономика, 1964. $-136 \mathrm{c}$.

41. Попов, Г. Х. В первых рядах строителей коммунизма / Г. Х. Попов. - М. : Московский международный университет, 2018. - 636 с.

42. Поручение Зимянина М.В. // РГАНИ. Ф. 5. - Оп. 73. - Д. 248. -8 л.

43. Саркисян, Г. С. Социальная политика и повышение народного благосостояния в условиях развитого социализма / Г. С. Саркисян // Доходы трудящихся и социальные проблемы уровня жизни населения СССР. - М. : НИИ труда, 1973. - С. 4-15.

44. Сибирев А. И. Ленинские идеи хозрасчета и претворение их в жизнь / А. И. Сибирев. - Л. : Знание, 1969. - 21 с.

45. Смирнов, Г. Л. XXIV съезд КПСС и формирование нового человека / Г. Л. Смирнов. - М. : Знание, 1972. - 48 c.

46. Смирнов, Г. Л. Советский человек: формирование социалистического типа личности / Г. Л. Смирнов. - М. : Политиздат, 1971. - 463 с.

47. Стенограмма выступления Г.Л. Смирнова, 1967 г. // РГАНИ. - Ф. 104. - Оп. 1. - Д. 25. - 21 л.

48. Стенограмма Международного совещания коммунистических и рабочих партий, 1969 г. // РГАНИ. - Ф. 10. - ОП. 1. - Д. 309. - 108 л.

49. Стенограммы заседаний Ученого совета АОН при ЦК КПСС // РГАСПИ. - Ф. 606. - ОП. 1. Д. $383 .-450$ л.

50. Стенограммы зональных совещаний идеологических работников РСФСР // РГАНИ. - Ф. 5. Оп. 34. - Д. 119. - 275 л.

51. Терешков, И. И. Материальное и моральное стимулирование труда: экономические основы, новые формы и системы: опыт БССР и других союзных республик / И. И. Терешков. - Минск : БНИИ НТИ и ТЭИ, 1981. - 50 с.

52. Федосеев, П. Диалектика развития социализма / П. Федосеев // Коммунист. - 1965. - № 14. C. $18-29$.

53. Хинчук, В. М. Законодательство о жилищных, дачных и гаражных кооперативах / В. М. Хинчук. - М. : Московский рабочий, 1975. - 95 с.

54. Шаттенберг, С. Леонид Брежнев : Величие и трагедия человека и страны / С. Шаттенберг. М. : Политическая энциклопедия, 2018. -623 с.

55. Шатунова, Т. М. Что случилось с социализмом в России? / Т. М. Шатунова // Socio Time. Coциальное время. - 2017. - № 1. - С. 30-39.

56. Armstrong, J. A. Ideology, Politics, and Government in the Soviet Union: An Introduction / J. A. Armstrong. - New York ; Washington : Praeger Publishers, 1974. - 236 p.

57. Churchward, L. G. The Soviet Intelligentsia: An Essay on the Social Structure and Roles of the Soviet Intellectuals During the 1960s / L. G. Churchward. - 


\section{ИСТОРИЧЕСКИЙ ОПЫТ ПОЛИТИЧЕСКИХ ТРАНСФОРМАЦИЙ}

London ; Boston : Routledge \& Keagan Paul, 1973. $204 \mathrm{p}$.

58. Colton, T. J. The Dilemma of Reform in the Soviet Union / T. J. Colton. - New York : Council on Foreign Affairs, 1986. $-120 \mathrm{p}$.

59. Thompson, T. L. Ideology and Policy: The Political Uses of Doctrine in the Soviet Union / T. L. Thompson. - Boulder ; San Francisco ; London : Westview Press, 1989. - 220 p.

\section{REFERENCES}

1. Aleksandrov A.I. Material'noe i moral'noe stimulirovanue truda - vazhnye factory povysheniya effektivnosti $i$ kachestva [Material and Moral Incentives of Labor - Important Factors for Improving Efficiency and Quality]. Leningrad, Izd-vo SKhI, 1978. 20 p.

2. Balans denezhnyh dokhodov i raskhodov naseleniya SSSR, 1924-1990 gg. (Evolyutsiya v tsifrakh, personaliyakh $i$ metodicheskom obespechenii): sb. mattrialov [Balance of Monetary Incomes and Expenditures of the Population of the USSR, 1924-1990 (Evolution in Numbers, Personnel and Methodological Support): Collection of Materials]. Moscow, MBI, 2007.308 p.

3. Bromley N.Ya. Uroven' zhizni v SSSR (19501965 gg.) [The Standard of Living in USSR (1950 1965)]. Voprosy istorii [Questions of History], 1966, no. 7, pp. 3-17.

4. Burlatskiy F. O stroitel'stve razvitogo sotsialisticheskogo obshchestva [Regarding the Construction of a Developed Socialist Society]. Pravda, 1966, 21 December, p. 4.

5. Vestnik Arhiva Prezidenta: Spetsial'noe izdanie: General'nyi sekretar' L.I. Brezhnev: 19641982 [Bulletin of the Presidential Archive: Special Edition: General Secretary Leonid Brezhnev: 19641982]. Moscow, 2006. 240 p.

6. Voslenskyi M. Nomenklatura [Nomenklature]. Moscow, Zakharov Publ., 2016. 640 p.

7. Goland Yu., Nekipelov A. Kosyginskaya reforma: upushchennyi shans ili mirazh? [Kosygin Reform: Lost Chance or Mirage?]. Rossiysky ekonomichecky zhurnal [Russian Economical Journal], 2010, no. 6, pp. 44-66.

8. Gushchin A.A. Obostrenie problemy tovarnogo defitsita v SSSR v 1960-kh - nachale 1980-kh gg. v rakurse istorii povsednevnosti [Aggravation of the Problem of Commodity Deficit in the USSR in the 1960s - Early 1980s in the Perspective of the History of Everyday Life]. Problemy gumanitarnogo obrazovaniya: filologiya, zhurnalistika, istoriya [The Problems of Humanitarian Education: Philology, Journalism, History]. Penza, Izd-vo PGU, 2016, pp. 252-258.
9. XXVI s'ezd Kommunisticheskoy partii Sovetskogo Soyuza: stenogr. otchet $\left[26^{\text {th }}\right.$ Congress of the Communist Party of the Soviet Union: Verbatim Report]. Moscow, Politizdat Publ., 1981, vol. 1. 382 p.

10. Dokumenty po podgotovke materialov XXIV s'ezda KPSS [Documents on Preparation of Materials of the $24^{\text {th }}$ Congress of CPSU]. Rossiysky gosudarstvenny arkhiv noveyshey istorii (RGANI) [Russian State Archive of Contemporary History], f. 80, op. 1, d. 100. 1011.

11. Zamechaniya L.I. Brezhneva, 1971 [Notes of L.I. Brezhnev, 1971]. RGANI, f. 104, op. 1, d. 41.631.

12. Zapiski otdela, politorganov [Memos of Department, Party Bodies]. RGANI, f. 5, op. 60, d. 39. 671.

13. Zapiski otdela, politorganov [Memos of Department, PartyBodies]. RGANI, f. 5, op. 63, d. 88. 2081.

14. Zapiski otdelov TsK KPSS [Memos of Departments of the CC of CPSU]. RGANI, f. 5, op. 64, d. 71.2471 .

15. Zapiski otdelov TsK KPSS [Memos of departments of the CC of CPSU]. RGANI, f. 5, op. 67, d. 110.2461.

16. Zapiski otdelov TsK KPSS [Memos of departments of the CC of CPSU]. RGANI, f. 5, op. 73, d. 243.221 .

17. Zapiski, pis'ma [Memos, Letters]. RGANI, f. 5, op. 33, d. 224. 1901.

18. Zapiski, pis'ma [Memos, Letters]. RGANI, f. 5, op. 59, d. 24.1481.

19. Zapiski, pis'ma Vsesoyuznogo obshchestva «Znanie» [Memos, Letters of the "Znanie" All-Union Society]. RGANI, f. 5, op. 33, d. 241. 241.

20. Zdravomyslov A.G. Sotsial'no-politicheskie aspekty mehanizma tormozheniya [Socio-Political Aspects of the Mechanism of Inhibition]. Mekhanizm tormozheniya: istoki, deystivie, puti preodoleniya [The Mechanism of Inhibition: Sources, Action, Ways of Overcoming]. Moscow, Politizdat Publ., 1988, pp. 9-24.

21. Informatsii (Baumansky RK KPSS) [Information Note (Baumansky District Committee of CPSU)]. Central'ny gosudarstvenny arkhivg. Moskvy (TSGAM) [Central State Archive of the City of Moscow], f. P-63, op. 1, d. 2247. 1201.

22. Informatsii (Baumansky RK KPSS) [Information Note (Baumansky District Committee of CPSU)]. Ts GAM, f. P-63, op. 1, d. 2288. 1311.

23. Informatsii (Baumansky RK KPSS) [Information Note (Baumansky District Committee of CPSU)]. TSGAM, f. P-63, op. 1, d. 2417. 1011.

24. Informatsii (Baumansky RK KPSS) [Information Note (Baumansky District Committee of CPSU)]. TsGAM, f. P-63, op. 1, d. 2463. 1431.

25. Informatsii (Baumansky RK KPSS) [Information Note (Baumansky District Committee of CPSU)]. TS GAM, f. P-63, op. 1, d. 2500. 1901. 
26. Informatitsii (MGK KPSS) [Information Note (Moscow City Committee of CPSU)]. Ts GAM, f. P-4, op. 172 , d. 50.1931.

27. Informatsii (Proletarsky RK KPSS) [Information Note (Proletarsky District Committee of CPSU)]. Ts $G A M$, f. P-80, op. 1, d. 1788. 1241.

28. Informatsii (Sokol'nichesky RK KPSS) [Information Note (Sokolnichesky District Committee of CPSU)]. $T_{s} G A M$, f. P-85, op. 1, d. 2262. 1681.

29. Kirsanov R.G. Sostoyanie potrebitel'skogo rynka v SSSR (konets 1970-h - nachalo 1990-h gg.) [The State of the Consumer Market in the USSR (Late 1970s - Early 1990s)]. Vestnik Buryatskogo gosudarstvennogo universiteta [The Bulletin of the Buryatia State University], 2014, no. 7, pp. 36-41.

30. Klinova M.A. Normy ratsional'nogo pitaniya v SSSR vtoroy poloviny 1950-h - 1980-h gg.: prichiny i vektornost' transformatsiy [Norms of Rational Nutrition in the USSR in the Second Half of the 1950s 1980s: Causes and Vectors of Transformations]. Uchenye zapiski: elektron. nauch. zhurn. Kurskogo gos. un-ta. Istoricheskie nauki i arkheologiya [Scientific Notes: Electronic Scientific Journal of the Kursk State University. Historical Sciences and Archeology], 2017, no. 4 (44), pp. 73-78. URL: http:// scientific-notes.ru/\#new-number?id=49 (accessed 18 August 2020).

31. Kozlov G. Ob etapah razvitiya kommunisticheskogo sposoba proizvodstva [Regarding the Stages of Development of the Communist Mode of Production]. Voprosy ekonomiki [Questions of Economy], 1971, no. 7, pp. 115-128.

32. Komarov V.E., Chernyavskiy U.G. Dohody $i$ potreblenie naseleniya SSSR [Incomes and Consumption of the Population of the USSR]. Moscow, Nauka Publ., 1973. 238 p.

33. Kommunisticheskaya partiya Sovetskogo Soyuza v rezolyutsiyah i resheniyah s'ezdov, konferentsiy i plenumov TsK [The Communist Party of the Soviet Union in Resolutions and Decisions of Congresses, Conferences and Plena of the Central Committee]. Moscow, IML pri TsK KPSS, 1987, vol. 13. 509 p.

34. Kosolapov R. Vklad XXIV, XXV i XXVI s'ezdov KPSS v razrabotku teoreticheskih i politicheskih problem razvitogo sotsializma i perehoda $\mathrm{k}$ kommunizmu [Contribution of the $24^{\text {th }}, 25^{\text {th }}$ and $26^{\text {th }}$ Congresses of the CPSU to the Development of Theoretical and Political Problems of Developed Socialism and the Transition to Communism]. Kommunist [The Communist], 1982, no. 5, pp. 54-67.

35. Mal'tsev N.A. Material'noe $i$ moral'noe stimulirovanie truda $v$ promyshlennosti [Material and Moral Stimulation of Labor in Industry]. Moscow, Mysl' Publ., 1965.95 p.

36. Material'noe i moral'noe stimulirovanie rabotnikov i predpriyatiy [Material and Moral
Stimulatinon of Workers and Enterprises]. Kiev, Znanie Publ., 1976. 29 p.

37. Mihaylov M., Motylev A. Chto reshil sentyabr'skiy plenum TsK KPSS: Mery po dal'neyshemu povysheniyu blagosostoyaniya sovetskogo naroda [What the September Plenum of the CPSU Central Committee Decided: Measures to Further Improve the Welfare of the Soviet People]. Moscow, Politizdat Publ., 1967.32 p.

38. Perepiska redaktsii zhurnala «Kommunist» [Editorial Correspondence of the "Kommunist" Magazine]. Rossyisky gosudarstvenny arkhiv sotsial'no-politicheskoy istorii (RGASPI) [Russian State Archive of Socio-Political History], f. 599, op. 1, d. 274.1161.

39. Perepiska redaktsii zhurnala «Kommunist» [Editorial Correspondence of the "Kommunist" Magazine]. RGASPI, f. 599, op. 1, d. 692. 1081.

40. Meier V.F., Krylov P.N., eds. Planirovanie narodnogo potrebleniya $v$ SSSR (sovremennye problemy) [Planning of National Consumption in the USSR (Modern Problems)]. Moscow, Ekonomika Publ., 1964. $136 \mathrm{p}$.

41. Popov G.H. V pervyh ryadah stroiteley kommunizma [In the First Ranks of the Communism Builders]. Moscow, Moskovsky mezhdunarodny universitet, 2018. 636 p.

42. Poruchenie Zimyanina M.V. [Instruction of M.V.Zimyanin]. RGANI, f. 5, op. 73, d. 248. 81.

43. Sarkisyan G.S. Sotsial'naya politika i povyshenie narodnogo blagosostoyaniya $\mathrm{v}$ usloviyah razvitogo sotsializma [Social Policy and the Improvement of People's Welfare under Developed Socialism]. Dohody trudyashchihsya i sotsialnye problemy urovnya zhizni naseleniya SSSR [The Incomes of Working People and Social Problems of the Life Standard of Population in the USSR]. Moscow, NII Truda, 1973, pp. 4-15.

44. Sibirev A.I. Leninskie idei hozrascheta $i$ pretvorenie ih v zhizn' [Lenin's Ideas of Self-Financing and Their Implementation]. Leningrad, Znanie Publ., 1969. $21 \mathrm{p}$.

45. Smirnov G.L. XXIV s'ezd KPSS i formirovanie novogo cheloveka $\left[24^{\text {th }}\right.$ Congress of the CPSU and the Formation of a New Human Being]. Moscow, Znanie Publ., 1972. 48 p.

46. Smirnov G.L. Sovetskiy chelovek: formirovanie sotsialisticheskogo tipa lichnosti [The Soviet Human Being: Formation of a Socialist Type of Personality]. Moscow, Politizdat Publ., 1971. 463 p.

47. Stenogramma vystupleniya G.L. Smirnova, 1967 g. [Verbatim of the G.L. Smirnov's Speech]. RGANI, f. 104, op. 1, d. 25. 211.

48. Stenogramma Mezhdunarodnogo soveshchaniya kommunisticheskikh i rabochikh partiy, 1969 g. [Verbatim of the International Meeting of 


\section{ИСТОРИЧЕСКИЙ ОПЫТ ПОЛИТИЧЕСКИХ ТРАНСФОРМАЦИЙ}

Communist and Workers' Parties, 1969]. RGANI, f. 10, op. 1, d. 309. 1081.

49. Stenogrammy zasedaniy Uchenogo soveta AON pri TSK KPSS [Verbatim of Meetings of the Academy of Social Sciences at the CC of the CPSU]. $R G A S P I$, f. 606, op. 1, d. 383. 4501.

50. Stenogrammy zonal'nyh soveshchaniy ideologicheskih rabotnikov RSFSR [Verbatim of Meetings of Ideological Workers of RSFSR]. RGANI, f. 5, op. 34, d. 119. 2751.

51. Tereshkov I.I. Material'noe i moral'noe stimulirovanie truda: ekonomicheskie osnovy, novye formy i sistemy: opyt BSSR $i$ drugih soyuznyh respublik [Material and Moral Stimulation of Labor: Economic Foundations, New Forms and Systems: The Experience of the BSSR and Other Republics]. Minsk, BNII NTI i TEI, 1981. $50 \mathrm{p}$.

52. Fedoseev P. Dialektika razvitiya sotsializma [Dialectics of the Development of Socialism]. Kommunist [The Communist], 1965, no. 14, pp. 18-29.

53. Hinchuk V.M. Zakonodatel'stvo o zhilishchnyh, dachnyh i garazhnyh kooperativah [Legislation on Housing, Dacha and Garage Cooperatives]. Moscow, Moskovsky rabochy Publ., 1975. 95 p.
54. Schattenberg S. Leonid Brezhnev: Velichie i tragediya cheloveka i strany [Leonid Brezhnev: The Greatness and Tragedy of Man and the Country]. Moscow, Politicheskaya entsiklopediya Publ., 2018. 623 p.

55. Shatunova T.M. Chto sluchilos's sotsializmom v Rossii? [What Happened to Socialism in Russia?]. Socio Time, 2017, no. 1, pp. 30-39.

56. Armstrong J.A. Ideology, Politics, and Government in the Soviet Union: An Introduction. New York; Washington, Praeger Publishers, 1974. $236 \mathrm{p}$.

57. Churchward L.G. The Soviet Intelligentsia: An Essay on the Social Structure and Roles of the Soviet Intellectuals During the 1960s. London; Boston, Routledge \& Keagan Paul, 1973. 204 p.

58. Colton T.J. The Dilemma of Reform in the Soviet Union. New York, Council on Foreign Affairs, 1986. $120 \mathrm{p}$.

59. Thompson T.L. Ideology and Policy: The Political Uses of Doctrine in the Soviet Union. Boulder; San Francisco; London, Westview Press, 1989. 220 p.

\section{Information About the Author}

Fedor L. Sinitsyn, Doctor of Sciences (History), Leading Researcher, Institute of World History of the Russian Academy of Sciences, Prosp. Leninsky, 32a, 119334 Moscow, Russian Federation, permcavt@gmail.com, https://orcid.org/0000-0003-2299-204X

\section{Информация об авторе}

Федор Леонидович Синицын, доктор исторических наук, ведущий научный сотрудник, Институт всеобщей истории РАН, просп. Ленинский, 32а, 119334 г. Москва, Российская Федерация, permcavt@gmail.com, https://orcid.org/0000-0003-2299-204X 